\title{
Profil HIV/AIDS di Bagian Ilmu Kesehatan Anak RSUP Prof. Dr. R.D. Kandou Manado Periode Januari 2009 sampai dengan Desember 2018
}

\author{
Yurissco B. Sumampouw, ${ }^{1}$ Novie H. Rampengan, ${ }^{2}$ Max F. J. Mantik ${ }^{2}$
}

\author{
${ }^{1}$ Program Studi Pendidikan Dokter Fakultas Kedokteran Universitas Sam Ratulangi Manado \\ ${ }^{2}$ Bagian Ilmu Kesehatan Anak Fakultas Kedokteran Universitas Sam Ratulangi Manado \\ Email: yurissco.sumampouw@gmail.com
}

\begin{abstract}
Human immunodeficiency virus (HIV) infection and acquired immunodpeficiency syndrome (AIDS) are health problems worldwide. Risk factors that are supposed to increase the incidence of HIV/AIDS include perinatal, homosexual, heterosexual, pattern of sexual relation, family with positive HIV/AIDS sufferers who do not use protective equipment, and injection drug users. This study was aimed to determine the profile of HIV/AIDS at the Department of Pediatrics Prof. Dr. R. D. Kandou Manado. This was a descriptive and retrospective study using data of Voluntary Counseling Test (VCT) from January 2009 to December 2018. The results showed that there were 75 patients, most were 13-18 years (32\%) and male sex $(50.67 \%)$. The most common transmission was perinatal transmission $(68 \%)$. Stage III had the highest percentage $(80 \%)$. First-line therapy was found as the most common (68\%), albeit 23 patients $(30.7 \%)$ had not received ARV therapy. There were 28 patients $(37.33 \%)$ who lived with HIV/AIDS. In conclusion, the highest prevalence of HIV was in 2018 and the most common patients were male, aged 13-18<18 years, and had perinatal transmission. and 28 children living with HIV. Some patients still lived with HIV/AIDS.
\end{abstract}

Keywords: human immunodeficiency virus, acquired immunodeficiency syndrome

\begin{abstract}
Abstrak: Infeksi human immunodeficiency virus (HIV) dan acquired immunodeficiency syndrome (AIDS) merupakan masalah kesehatan di dunia. Faktor-faktor risiko yang diperkirakan meningkatkan angka kejadian HIV/AIDS antara lain: perinatal, homoseksual, heteroseksual, pola hubungan seks, keluarga dengan pengidap HIV/AIDS positif yang tidak menggunakan pelindung, dan pemakai alat suntik. Penelitian ini bertujuan untuk mengetahui profil HIV-AIDS di Bagiaan Ilmu Kesehatan Anak RSUP Prof. Dr. R. D. Kandou. Jenis penelitian ialah deskriptif retrospektif. Penelitian ini menggunakan data dari Voluntary Counseling Test (VCT) RSUP Prof. Dr. R.D. Kandou Manado selama Januari 2009-Desember 2018. Hasil penelitian mendapatkan 75 pasien dan yang terbanyak ialah usia 13-18 tahun (32\%), dan jenis kelamin laki-laki $(50,67 \%)$. Penularan terbanyak ialah perinatal $(68 \%)$ Stadium terbanyak ialah stadium III (80\%) dan terapi lini I yang terbanyak $(68 \%)$ namun terdapat 23 pasien $(30,7 \%)$ yang belum mendapatkan terapi ARV. Terdapat 28 pasien $(37,33 \%)$ yang hidup dengan HIV/AIDS. Simpulan penelitian ini ialah prevalensi tertinggi HIV pada tahun 2018 dan pasien yang terbanyak berjenis kelamin laki-laki, usia 13-<18 tahun, dengan penularan perinatal. Sebagian pasien hidup dengan HIV/AIDS.
\end{abstract}

Kata kunci: human immunodeficiency virus, acquired immunodeficiency syndrome

\section{PENDAHULUAN}

Infeksi human immunodeficiency virus (HIV) dan acquired immunodeficiency syndrome (AIDS) merupakan masalah kesehatan di dunia. ${ }^{1}$ Di seluruh dunia, 35 juta orang hidup dengan HIV yang meliputi 16 juta perempuan dan 3,2 juta anak $<15$ tahun dan terdapat 19 juta orang tidak mengetahui status HIV positif mereka. ${ }^{2}$ Infeksi HIV dan AIDS, diperkirakan 70\% 
di Afrika dan 30\% di Asia. Meskipun jumlah infeksi terbanyak adalah di Afrika, peningkatan paling cepat dalam infeksi HIV dalam dekade terakhir telah terjadi di negara-negara Asia Tenggara, termasuk Thailand, dan India. ${ }^{3}$

Indonesia merupakan negara urutan ke5 paling berisiko HIV/AIDS di Asia. Di Indonesia HIV/AIDS pertama kali ditemukan di Provinsi Bali pada tahun 1987. ${ }^{4}$ Sejak pertama kali dilaporkan pada tahun 1987 sampai dengan Juni 2018, HIV/AIDS telah dilaporkan oleh $433(84,2 \%)$ dari 514 kabupaten/kota di seluruh provinsi di Indonesia.,

Kasus infeksi HIV di Indonesia terus meningkat. Menurut World Health Organization (WHO) pada tahun 2015, jumlah orang yang hidup dengan HIV di Indonesia 690.000, dan dari jumlah tersebut, 17.000 adalah anak-anak berusia 0-14 tahun. ${ }^{6}$ Terdapat 6,5 juta perempuan menjadi populasi rawan tertular dan menularkan, dan lebih dari 9.000 perempuan hamil dengan HIV positif dalam setiap tahunnya, dan lebih dari 30\% (3000 ibu hamil) di antaranya akan melahirkan bayi yang tertular bila tidak ada pencegahan penularan dari ibu HIV positif kepada bayi. ${ }^{7}$

Pola penularan HIV pada pasangan seksual berubah pada saat ditemukan kasus seorang ibu yang sedang hamil diketahui telah terinfeksi HIV. Bayi yang dilahirkan ternyata juga positif terinfeksi HIV. Hal ini menjadi awal dari penambahan pola penularan HIV/AIDS dari ibu ke bayi yang dikandungnya. Hal serupa digambarkan dari hasil survei pada tahun 2000 di kalangan ibu hamil di Provinsi Riau dan Papua yang memperoleh angka kejadian infeksi HIV $0,35 \%$ dan $0,25 \%$. Hasil tes sukarela pada ibu hamil di DKI Jakarta ditemukan infeksi HIV sebesar 2,86\%. Berbagai data tersebut membuktikan bahwa epidemi AIDS telah masuk kedalam keluarga yang selama ini dianggap tidak mungkin tertular infeksi. ${ }^{8}$

Penularan HIV ke bayi dan anak, bisa terjadi selama proses persalinan melalui transfusi fetomaternal atau kontak antara kulit atau membran mukosa bayi dengan darah atau sekresi maternal saat melahirkan. ${ }^{9}$ Jumlah ibu hamil yang terinfeksi HIV dari tahun ke tahun semakin meningkat, seiring dengan meningkatnya jumlah lakilaki yang melakukan hubungan seksual tidak aman, yang selanjutnya akan menularkan pada pasangan seksualnya dan akan berdampak pada bayi yang dikandung ibu hamil sebab penularan HIV dari ibu ke bayi merupakan akhir dari rantai penularan HIV. HIV yang ditularkan dari ibu kepada anaknya disebut mother to child HIV transmission (MTCT). Penularan HIV dari ibu ke bayi mencapai hingga $90 \%$ kasus. ${ }^{10}$

Transmisi lain juga terjadi selama periode postpartum melalui ASI. Infeksi HIV umumnya ditularkan melalui kontak langsung antara membran mukosa atau aliran darah dengan cairan tubuh yang mengandung HIV, seperti darah, air mani, dan cairan vagina. Penularan dapat terjadi melalui hubungan intim (vaginal, anal, ataupun oral), transfusi darah, atau jarum suntik yang terkontaminasi. ${ }^{9-11}$

Faktor-faktor risiko yang diperkirakan meningkatkan angka kejadian HIV/AIDS antara lain: lingkungan sosial ekonomi khususnya kemiskinan, latar belakang kebudayaan/etnis, Keadaan demografi (banyaknya pelabuhan yang disinggahi orang asing). Kelompok masyarakat yang berpotensi risiko tinggi HIV ialah: status donor darah bayi dari ibu yang dinyatakan menderita AIDS (proses kehamilan, kelahiran, dan pemberian ASI), pecandu narkotik (khususnya tindikan dengan alat yang terpapar HIV/AIDS), wanita pekerja seks, homoseksual dan heteroseksual, pola hubungan seks, keluarga dengan penderita HIV/AIDS positif yang tidak menggunakan pelindung, dan pemakai alat suntik sangat mungkin tertular HIV dan AIDS. ${ }^{12}$

Berdaasarkan latar belakang yang telah diuraikan, peneliti ingin mengetahui profil HIV/AIDS di Bagian Ilmu Kesehatan Anak RSUP Prof. Dr. R. D. Kandou Manado periode Januari 2009 s/d Desember 2018.

\section{METODE PENELITIAN}

Jenis penelitian ini ialah deskriptif retrospektif. Populasi penelitian ini ialah 
semua pasien anak yang terdiagnosis HIV/ AIDS di Bagian Ilmu Kesehatan Anak RSUP Prof Dr. R. D. Kandou periode Januari 2009 s/d Desember 2018.

Data penelitian diperoleh dari data Voluntary Counseling Test (VCT) RSUP Prof. Dr. R. D. Kandou Manado periode Januari 2009 sampai dengan Desember 2018. Variabel penelitian ini ialah usia, jenis kelamin, penularan, stadium klinis, terapi ARV, keadaan pasien, dan stadium klinis.

Penelitian ini telah mendapat persetujuan dari Komisi Etik Penelitian Kesehatan RSUP Prof. Dr. R. D. Kandou Manado, dengan nomor keterangan layak etik yaitu No. 066/EC/KEPK-KANDOU/X/2019.

\section{HASIL PENELITIAN}

Penelitian ini dilakukan secara retrospektif di Voluntary Counseling Test (VCT) RSUP Prof. Dr. R. D. Kandou Manado selama Januari 2009 s/d Desember 2018. Terdapat 75 pasien terdiri dari 38 anak laki-laki $(50,67 \%)$ dan 37 anak perempuan $(49,33 \%)$.

Tabel 1 memperlihatkan distribusi pasien HIV/AIDS menurut golongan usia. Golongan usia 13-<18 tahun merupakan yang terbanyak dengan jumlah pasien sebanyak 24 anak (32\%) sedangkan yang paling sedikit ialah golongan usia 6-12 tahun berjumlah 11 anak $(14,7 \%)$.

Tabel 1. Distribusi pasien HIV/AIDS berdasarkan usia

\begin{tabular}{ccc}
\hline $\begin{array}{c}\text { Golongan usia } \\
\text { (tahun) }\end{array}$ & Jumlah & $\begin{array}{c}\text { Persentase } \\
(\boldsymbol{\%})\end{array}$ \\
\hline$<1$ & 18 & 24 \\
$1-5$ & 22 & 29,3 \\
$6-12$ & 11 & 14,7 \\
$13-<18$ & 24 & 32 \\
Total & 75 & 100 \\
\hline
\end{tabular}

Tabel 2 memperlihatkan distribusi pasien HIV/AIDS menurut cara penularan. Pasien dengan penularan secara perinatal yang terbanyak dengan jumlah 51 anak (68\%). Berdasarkan jenis kelamin untuk penularan perinatal, terdapat 26 anak laki- laki (51\%) dan 25 anak perempuan (49\%). Pada penularan secara homoseks dengan jumlah 12 anak (16\%) didapatkan semuanya berjenis kelamin laki-laki (100\%). Pada penularan secara heteroseks dengan jumlah 12 anak (16\%) didapatkan semuanya berjenis kelamin perempuan (100\%).

Tabel 2. Distribusi pasien HIV/AIDS berdasarkan cara penularan

\begin{tabular}{ccc}
\hline Penularan & Jumlah & $\begin{array}{c}\text { Persentase } \\
(\mathbf{\%})\end{array}$ \\
\hline Heteroseks & 12 & 16 \\
Perinatal & 51 & 68 \\
Homoseks & 12 & 16 \\
Total & 75 & 100 \\
\hline
\end{tabular}

Tabel 3 memperlihatkan distribusi pasien HIV/AIDS menurut stadium klinis. Pasien dengan stadium klinis III yang terbanyak dengan jumlah 60 anak $(80 \%)$ dan yang paling sedikit ialah dengan stadium klinis IV berjumlah 0 pasien $(0 \%)$.

Tabel 3. Distribusi pasien HIV/AIDS berdasarkan stadium klinis

\begin{tabular}{ccc}
\hline Stadium & Jumlah & $\begin{array}{c}\text { Persentase } \\
(\%)\end{array}$ \\
\hline I & 11 & 14,7 \\
II & 4 & 5,3 \\
III & 60 & 80 \\
IV & 0 & 0 \\
Total & 75 & 100 \\
\hline
\end{tabular}

Tabel 4 memperlihatkan distribusi pasien HIV/AIDS menurut pemberian terapi ARV. Terapi lini I didapatkan yang terbanyak dengan jumlah 51 pasien $(68 \%)$. Terdapat 23 pasien $(30,7 \%)$ yang belum mendapatkan terapi ARV.

Tabel 4. Distribusi pasien HIV/AIDS berdasarkan terapi ARV

\begin{tabular}{ccc}
\hline Terapi ARV & Jumlah & $\begin{array}{c}\text { Persentase } \\
(\mathbf{\%})\end{array}$ \\
\hline Lini I & 51 & 68 \\
Lini II & 1 & 1,3 \\
Belum & 23 & 30,7 \\
Total & 75 & 100 \\
\hline
\end{tabular}


Tabel 5 memperlihatkan distribusi pasien HIV/AIDS menurut keadaan pasien. Terdapat 35 pasien $(46,67 \%)$ yang meninggal dengan HIV/AIDS, 28 pasien $(37,33 \%)$ hidup dengan HIV/AIDS, dan 12 pasien (16\%) lost to follow up (LFU).

Tabel 5. Distribusi berdasarkan keadaan pasien HIV/AIDS

\begin{tabular}{ccc}
\hline $\begin{array}{c}\text { Keadaan } \\
\text { pasien }\end{array}$ & Jumlah & $\begin{array}{c}\text { Persentase } \\
(\%)\end{array}$ \\
\hline Meninggal & 35 & 46,67 \\
Hidup & 28 & 37,33 \\
Lost to & 12 & 16 \\
follow up & 75 & 100 \\
Total & 75 \\
\hline
\end{tabular}

\section{BAHASAN}

Berdasarkan data Voluntary Counseling Test (VCT) pada pasien HIV/AIDS yang dirawat di Bagian Ilmu Kesehatan Anak RSUP Prof. Dr. R. D. Kandou periode waktu Januari 2009-Desember 2018 diperoleh sebanyak 75 pasien. Angka kejadian tertinggi HIV/AIDS terjadi pada tahun 2018 yaitu 12 kasus (16\%) dan angka kejadian terendah terjadi pada tahun 2009 yaitu 3 kasus (4\%).

Saat fase awal setelah terinfeksi virus HIV, masa inkubasi terjadi 2-4 minggu pertama dan tanpa gejala. Selanjutnya pada pada fase infeksi akut, muncul gejala berupa flu, demam, sakit kepala, dan limfadenopati; fase ini berlangsung selama 28 hari sampai beberapa minggu. Fase ini diikuti oleh fase laten yang berlangsung 5 sampai 10 tahun, gejala hampir tidak ada tetapi virus aktif berkembang dan menghancurkan sistem imun tubuh. Pada penelitian didapatkan pasien berusia 13$<18$ tahun merupakan golongan usia terbanyak yang menderita HIV/AIDS yaitu berjumlah 24 anak (32\%), disusul golongan usia 1-5 tahun berjumlah 22 pasien $(29,3 \%)$, golongan usia $<1$ tahun berjumlah 18 pasien (24\%), dan golongan usia 6-12 tahun berjumlah 11 pasien (14,7\%). Berbeda dengan penelitian yang dilakukan di RS Wahidin Sudirohusodo Makasar yaitu yang paling banyak (50\%) mengidap HIV/ AIDS ialah usia 5-14 tahun. ${ }^{13,14}$
Berdasarkan distribusi pasien yang didiagnosis HIV/AIDS menurut jenis kelamin didapatkan bahwa jenis kelamin terbanyak ialah laki-laki dengan jumlah 38 pasien $(50,67 \%)$ sedangkan jenis kelamin perempuan berjumlah 37 pasien $(49,33 \%)$. Menurut laporan statistik Kemenkes RI pada tahun 2017, laki-laki yang terbanyak mengidap HIV/AIDS dengan jumlah 30.721 dan perempuan 17.579 orang. Hal ini disebabkan oleh perbedaan pola hidup laki-laki yang menyebabkannya berada pada risiko tertinggi HIV/AIDS seperti pecandu narkotika, homoseks dan heteroseks. ${ }^{12}$ Meskipun berdasarkan data statistik laki-laki lebih banyak terinfeksi HIV/AIDS daripada perempuan, pada penelitian ini didapatkan untuk periode 2009 sampai 2018, 3 tahun diantaranya peremuan lebih banyak dibandingkan laki-laki dan selama 2 tahun laki-kali dan perempuan berjumlah sama banyak. Hal ini tidak diberlakukan khususnya pada anak-anak karena pola penularan HIV/AIDS pada anak berbeda dengan orang dewasa.

Berdasarkan distribusi pasien yang didiagnosis HIV/AIDS menurut penularan terdapat 51 pasien $(68 \%)$ dengan penularan secara perinatal, kemudian penularan secara homoseks dengan jumlah 12 pasien (16\%), dan penularan secara heteroseks dengan jumlah 12 pasien (16\%).

Infeksi HIV/AIDS pada ibu hamil dapat mengancam kehidupan ibu serta ibu dapat menularkan virus kepada bayinya. Lebih dari $90 \%$ kasus anak terinfeksi HIV/AIDS melalui proses penularan dari ibu ke anak (MTCT). Data Kemenkes RI menyatakan penularan HIV/AIDS dari ibu ke anak dari 4.361 orang di tahun 2012 meningkat menjadi 5.565 orang di tahun 2016. ${ }^{7,10}$

Saat dinyatakan positif, pasien diklasifikasi secara klinis menurut stadium WHO. Distribusi pasien menurut stadium klinis memperlihatkan bahwa pasien dengan stadium klinis III yang terbanyak berjumlah 59 anak (78,67\%), disusul stadium klinis I dengan jumlah 11 anak dengan persentase $14,67 \%$, dan stadium klinis III dengan jumlah 5 anak dengan persentase $6,67 \%$. 
Kriteria sradium klinis III yakni penurunan berat badan $>10 \%$, diare, demam yang tidak diketahui penyebabnya lebih dari 1 bulan, kandidiasis oral atau vaginal, tuberkulosis paru (TB paru) dalam satu tahun terakhir, infeksi bakterial yang berat (pneumonia, piomiositis, dll), dan disertai penyakit oportunistik. ${ }^{13}$ Hasil penelitian ini agak berbeda dengan penelitian di RSUD Dr. T. C Hillers Maumere yang melaporkan bahwa stadium klinis IV yang tertinggi $(40,4 \%)$ dibandingkan stadium klinis III $(25 \%) .{ }^{16}$ Idealnya, VCT melakukan deteksi dini pasien masih dalam stadium awal sehingga rantai penularan dapat diputuskan termasuk pencegahan transmisi dari ibu ke janin.

Para pengidap HIV/AIDS memerlukan pengobatan dengan anti retroviral (ARV) untuk menurunkan jumlah virus HIV di dalam tubuh agar tidak masuk ke dalam stadium AIDS serta untuk mencegah terjadinya infeksi oportunistik dan komplikasinya. ${ }^{15}$ Hasil penelitian ini mendapatkan bahwa berdasarkan terapi ARV, 51 pasien (68\%) dengan terapi ARV lini I, 1 pasien $(1,3 \%)$ dengan terapi lini II; dan 23 pasien $(30,7 \%)$ belum mendapatkan terapi ARV. Data Kementerian Kesehatan RI pada tahun 2014 menyatakan penerima pengobatan ARV sebanyak 84.030 orang $(77,6 \%)$ dari 108.060 dan 24.030 orang $(22,24 \%)$ belum mendapatkan ARV. ${ }^{15}$

Berdasarkan keadaan pasien didapatkan 35 pasien $(46,67 \%)$ meninggal dengan HIV/AIDS, 28 pasien $(37,33 \%)$ hidup dengan HIV/AIDS, dan 12 pasien (16\%) lost to follow up (LFU). Data Badan Pusat Statistik Indonesia untuk Provinsi Sulawesi Utara tahun 2009 melaporkan dari 173 jumlah kasus terdapat 62 orang (36\%) meninggal dunia, dan pada tahun 2011 terjadi kenaikan yaitu dari 557 jumlah kasus dengan 125 orang (22\%) meninggal. ${ }^{16}$

\section{Konflik Kepentingan}

Penulis menyatakan tidak terdapat konflik kepentingan dalam studi ini.

\section{SIMPULAN}

Pada pasien anak yang terdiagnosis
HIV/AIDS di Bagian Ilmu Kesehatan Anak RSUP Prof Dr. R. D. Kandou periode Januari 2009 sampai dengan Desember 2018 didapatkan sebagian besar berjenis kelamin laki-laki. berusia $13-<18$ tahun, pola penularan secara perinatal, berada pada stadium klinis III, dan telah mendapatkan terapi ARV. Sebagian pasien hidup dengan mengidap HIV/AIDS.

Bagi anak sekolah dan remaja perlu dilakukan penyuluhan mengenai pentingnya perilaku hidup sehat dan tidak melakukan seks bebas. Penyuluhan dan peningkatan program Prevention Mother to Child Transmission (PMTCM) untuk menurunkan penularan dari ibu ke anak perlu digalakan serta tempat pelayanan untuk tes HIV dan konseling yang memadai mengenai HIV/AIDS perlu disosialisasikan.

\section{Konflik Kepentingan}

Penulis menyatakan tidak terdapat konflik kepentingan dalam studi ini.

\section{DAFTAR PUSTAKA}

1. World Health Organization. Epidemiological situation of HIV. HIV/AIDS in the South-East Asia region: progress report 2011. India: WHO, 2012.

2. Joint United Nations Programme on HIV and AIDS. UNAIDS. The gap report. 2014. Available from: http://www.depkes. go.id/resources/download/pusdatin/info datin/InfoDatin-HIV-AIDS-2018.pdf.

3. Kumar, Abbas, Fausto. Robbins and Cotran's Pathologic Basis of Disease (9th ed). [e-book]. Philadelphia: Saunders,2 004.

4. Pusat Data dan Informasi Kementrian Kesehatan RI. Situasi dan analisis HIV AIDS. 2014. Available from: http://www.depkes.go.id/download.php ?file=download/pusdatin/infodatin/Info datin\%20AIDS.pdf.

5. Kementerian Kesehatan RI. Direktorat Jendral Pencegahan dan Pengendalian Penyakit. Laporan perkembangan HIV-AIDS \& infeksi menular seksual (IMS) triwulan II;2018. Available from: http://siha.depkes.go.id/portal/files_upl oad/Laporan_Perkembangan_HIV_AI DS_dan_PIMS_TW_2_2018.pdf.

6. World Health Organization. Case Definition of HIV (1st ed). France: WHO, 2007. 
7. Kementrian Kesehatan Republik Indonesia. Pedoman Nasional Pencegahan Penularan HIV Dari Ibu Ke Anak (PPIA). Jakarta: Kemenkes. 2012.

8. Departemen Kesehatan Indonesia: Direktotat Jenderal Pengendalian Penyakit dan Penyehatan Lingkungan, Pedoman Tatalaksana Infeksi HIV dan Terapi Antiretroviral pada anak di indonesia. Jakarta: Depkes RI, 2008.

9. Huriarti. HIV/AIDS pada Anak [Skripsi]. Makassar: UIN Alauddin Makassar; 2014.

10. WHO and UNAIDS.A guide on indicators for monitoring and reporting on the health sector response to HIV/AIDS. 2011. Geneva, WHO. (14 November 2013). Available from: http://www.who.int/ hiv/data/tool2011/en.

11. Sudikno, Simanungkalit B, Siswanto. Pengetahuan HIV dan AIDS pada remaja Indonesia. Jurnal Kesehatan Reproduksi. 2011;1(3):145-54.

12. Nyoman S. Epidemiologi AIDS standarisasi diagnostik dan penatalaksanaan beberapa penyakit menular Seksual. Fakultas Kedokteran Universitas
Sumatera Utara, Jakarta.1990

13. WHO. Definisi Kasus HIV WHO. Surveillance dan revisi stadium klinis dan klasifikasi imunologis penyakit terkait HIV pada orang dewasa dan anak-anak. 2017.

14. Anastasia A. Karakteristik penderita HIV/AIDS pada anak di Rumah Sakit Wahidin Sudirohusodo Makassar periode Januari 2015-Mei 2017. Makassar: Universitas Hasanuddin; 2017

15. Kemenkes RI. Situasi dan Analisis HIV AIDS. Jakarta: Pusat Data dan Informasi Kementerian Kesehatan RI, 2014.

16. Badan Pusat Statistik Indoneisa. Kumulatif kasus HIV AIDS, kasus meninggal, rate kumulatif, dan jumlah kasus baru HIV AIDS. Indonesia, 2014. Available from: https://www.bps.go.id/ statictable/2014/09/10/1569/kumulatif -kasus-aids-kasus-meninggal-ratekumulatif-dan-jumlah-kasus-baruaids-menurut-provinsi-di-indonesia2008-2012.html 